\title{
Violence and "Counter-Violence". On Correct Rejection. A Sketch of a Possible Russian Ethics of War Considered through the Understanding of Violence in Tolstoy and in Petar II Petrović Njegoš
}

\author{
P. Bojanić ${ }^{1,2}$ \\ ${ }^{1}$ University of Belgrade \\ 1, Studentski trg, Belgrade, 11000, Serbia \\ ${ }^{2}$ Ural Federal University \\ 19, Mira Str., Ekaterinburg, 620002, Russian Federation
}

\begin{abstract}
The article's intention is to construct a possible minimal response to violence, that is, to describe what would be justified (necessary or legitimate) "противонасилие" (counter-violence). This argument is built on reviving several important philosophical texts in Russian of the first half of the twentieth century as well as on going beyond that historical moment. Starting with the reconstruction of Tolstoy's criticism of any use of violence, it is then shown that, paradoxically, resistance to Tolstoy's or 'pseudo'-Tolstoy's teachings ends up incorporating Tolstoy's thematization of counter-violence into various theories, which sought to legitimate the use of force. In particular, Tolstoy's discovery of a force, which, on the one hand, is not grounded in violence and, on the other hand, which is capable of countering violence, becomes fundamental in reasoning about the just use of force. The connection is made between Tolstoy and Petar II Petrović Njegoš, who also thematizes the use of force in Christian perspective. In his view, justice, "blessed by the Creator's hand," has the capacity to protect from violent force. Any living thing defends itself from what endangers it by means Creator bestowed it with. Living force and protective use of force are conceptually linked in Njegoš's reasoning. Thus, only protective force can defeat aggressive force. This is shown to be Njegoš's contribution to the Orthodox Christian discourse on violence. If a force can be counter-violent, the next step in our argument would be to search for a protocol that should have universal validity, that is, it has to be valid for all conflicting sides, The protocol of counter-violence requires that, firstly, it is a response to violence; secondly, it interrupts violence and forestalls any possible future violence (it is the 'last' violence); thirdly, it is subject to verification, it addresses those who are a priori against any response to violence (which usually refers to various forms of "Tolstoyism").

Finally, it is shown that state power does not create law, but it is being right that makes law or gives life to social order, and thereby can authorize the use of force. This is the innovation
\end{abstract}

(C) Bojanić P., 2020

This work is licensed under a Creative Commons Attribution 4.0 International License https://creativecommons.org/licenses/by/4.0/ 
in the histories of justification of force, absent in the West. Aggressive violence can necessarily be opposed only in the way that implies the possibility of constituting law and order.

Keywords: violence, counter-violence, justification of violence, Russian ethics of war and violence, Orthodox ethics of war and violence, Tolstoy's ethics, Ilyin's ethics

Funding and Acknowledgement of Sources. The work was supported by the Russian Science Foundation (grant \#20-18-00240).

\author{
Article history: \\ The article was submitted on 18.07.2020 \\ The article was accepted on 24.08.2020
}

For citation: Bojanić P. Violence and "Counter-Violence". On Correct Rejection. A Sketch of a Possible Russian Ethics of War Considered through the Understanding of Violence in Tolstoy and in Petar II Petrović Njegoš. RUDN Journal of Philosophy. 2020; 24 (4): 657-668. DOI: $10.22363 / 2313-2302-2020-24-4-657-668$

\title{
Introduction
}

Angeliki Laiou's text "The Just War of Eastern Christians the Holy War of the Crusaders" [1], which was supposed to be a contribution to Orthodox Christian understanding of war within an all-encompassing and general "ethics of war" (held in common by all religions of the world), advocates insufficiently for a real construction that would consider and justify the use of force potentially designated as Orthodox Christian or observant. Availing myself of the various arguments for justified violence made in Russian and other Slavic, but also Western languages, my intention, in this brief sketch of a future text or project, is to construct a possible minimal response to (a rejection of) violence, or indeed describe what would be justified (necessary or legitimate) "противонасилие" (counter-violence). For the use of force to be small, timely, and correct, its description would need to satisfy hypothetically two conditions: 1) the reflection on war and the force of Russian philosophers before and in the course of the Great War (a century ago now), would have to be recognized as truly the best model that Eastern Christianity uncovered in theory of violent acting. And 2) this model would necessarily have to be competitive and in harmony with already existing problems and arguments that comprise what in the Anglophone world is referred to as "the ethics of war" or "the ethics of (un)justly conducted war."

I would like to justify my decision to provide an argument by reviving a few important philosophical texts in Russian from a hundred years ago, as well as by expanding the problem across that historical moment. If we are invested in the notion that humanities and social sciences have a responsibility to continuously question the kinds of violence and its justification, revising old arguments and construct new institutes and institutions within which myriads of researchers might together seek and defend the limit of use of violence that cannot rationally be altered - then the engagement of these philosophers at the beginning of the last century could be analogous to a construction of a new theory of war in the last thirty years in English and in Hebrew. 
There are a few necessary conditions in producing an argument about war and use of military violence that are satisfied among these thinkers: a) generally the texts (and books) were produced simultaneously or immediately after one of the largest military conflicts to feature all great military powers; b) the war called 'great' was made such precisely by a convincing justification for the use of force and military actions by myriads of theorists (above all philosophers) of all states and in all languages, and celebrated (or resisted) by all important persons of that time; c) a confrontational or invested tone in elaborating thoughts on war or violence has meant that these texts are almost entirely devoid of so-called "religious phraseology," which is to say, they are not pamphlets and so are stripped of facile calls to war or denials about the importance of war. Meticulous argumentation, detailed reconstruction of reasons for and against the use of violence in various situations, theories of justification of the ongoing war that invariably evolve into reflections about war as such (or war in general), are the product of conflicts unfolding on multiple levels, forcing the authors to a sensitive and very considered way of writing:

- during the war, philosophers (of all nations) follow carefully what their counterparts in other countries are doing and writing about war. As an ensemble of events (events are changes that in one way or another alter the state of affairs, relations, structure of various factors), the war increases the philosophers' attention and sustains their vigilance.

- the conflict with the 'Germanic spirit' is an attempt to uncover the rationale of German militarism and connect German philosophy and culture in general with war, imperialism, and brutality. Similar attempts can be found, for example, in Durkheim or Bergson, some English authors, although a great number of Russian thinkers and philosophers provide rather original contributions in describing the 'Germanic' and its distinguishing characteristics in comparison to what is designated as "Russian."

- debates and fierce polemics among all these Russian philosophers (their reading of each other during the war is otherwise an entirely unremarkable fact) follow closely their opposition to the arguments of philosophers from enemy countries. These go far beyond mere conflict between war advocates and objectors, various philosophical groupings or associations, cities (such as 'peace-loving' Saint Petersburg vs. 'bellicose' Moscow); the debates are meant to indicate problems, but also advance the war effort, and thus lead to victory;

- war and the use of violence lead to continuous reconsideration of the previous Russian tradition of thinking about these issues. At the same time, this represents an attempt to significantly reconstruct a new model of meaning and justification of war that would best suit what could be called an "Orthodox Christian" or "Eastern Christian" understanding of war;

- the Great War and its terrible destruction introduce an explicit thematization of an Orthodox Christian and require a new model of conducting war, which is supposed to be diametrically opposed to the Jesuit (for Ilyin) or Western Christian 
understanding of just war. Russian or Orthodox Christian understanding of war a priori eliminates imperialism, the institution of aggressive war, as well as all forms of preventive use of violence;

- finally, the Great War and the seminal texts published at the time in Russian introduce another conflict that would split Russia and produce a great civil war. It seems to me that the thematization of justified and legitimate forms of violence conducted in times of war all become further complicated and mitigated in relation to an entirely new form of violence arising at the same time - revolutionary violence. The Great War that transforms and continues in the form of a civil war and revolution further shapes the search for a just use of force and stringent demand for correct response (rejection) of force, as well as an efficient end to violence.

\section{Philosophical discourse of counter-violence}

Let us return to the title, however, as there might be problems with the words 'counter' and 'reject' (oppose, rebuff, resist). Some of the words in the title, 'violence', 'counter-violence' (противонасилие), as well as non-violence (nenasiliye) are used only very rarely in the texts I have mentioned. There are a few reasons for this. The most basic is probably the attempt to circumvent a tradition heavily marked by the presence of Tolstoy and his theory of non-violence, which is not doing nasilovaniya ("coercions"; this is the word he uses). Tolstoy defines coercion as an action or gesture directed at one who does not wish it or does not choose to accept it. Both Ilyin and Frank accept Tolstoy's understanding of violence as aggressive brute force, making it by definition unjustified. Thus, opposition to violence (attack) should exclusively bear the name of force, but be distinct from violence. If the aggressor attacks, occupies, defaces, then the force standing in its way (deployed by the righteous) is really preventing, cutting them off, pacifying. Thus, such force would, paradoxically, be non-violent, contain no coercion.

This is a reconstruction of Tolstoy's key idea about discovery of a completely different and new force. Resistance to Tolstoy and his followers (chiefly by Ilyin and Frank, but they are far from being alone) results in very detailed and careful reading of Tolstoy's original works. Paradoxically, this resistance to Tolstoy's adherents or the Zeitgeist filled with various Tolstoy's or 'pseudo-Tolstoy' positions, ends up incorporating a kind of 'original' Tolstoy into its own theory of (non-)opposition to violence: it includes the discovery of a force (which Tolstoy later claims to be love) that is supposed to delay violence. Better put, it would appear that Tolstoy's positions from different periods are assembled together into a new thinking about war and force, and, as such, begin to regulate the ethics of just use of force.

I am not sure that it is possible to show coherently Tolstoy's position; but it is possible to list a few of his insights implicitly present in the texts dealing with war and violence. First, Tolstoy introduces a seriousness in understanding war as an extreme violence, calling for a rigorous thematization of war (although he does then all too quickly conclude that "war's purpose is murder". In the third volume of 
"War and Peace" we read: "War is not courtesy but the most horrible thing in life; and we ought to understand that and not play at war. We ought to accept this terrible necessity sternly and seriously" [2. P. 1456]. Further, he uses two original paths to question the accepted and trivial notion that society is grounded in war and violence: that violence cannot be a means of bringing people together (soyedineniya lyudey), that is, that violence alienates or is a false unifier, a "podobiye spravedlivosti," and only semblance of society. There is no thematization of violence, before or after Tolstoy, that contains this specifically constructed connection between life and violence. Tolstoy's attempt is to rid life of violence, or to uncover the force of life that is not or does not have to be grounded in violence. He puts forward two entirely original insights regarding state power (vlast) and its connection with violence (long before Michel Foucault): first, "the basis of authority is bodily violence" [3. P. 167], and second, "but ruling means using force, and using force means doing to him to whom force is used, what he does not like and what he who uses the force would certainly not like done to himself. Consequently, ruling means doing to others what we would not they should do unto us, that is, doing wrong" [3. P. 242]. Finally, Tolstoy's final operation, which reverberates across subsequent views of "non-violence," refers to the displacement of force (life force) from the outside world into the inner life of every individual: "(...) he who himself possesses sufficient power ...will not resort to violence" [4. P. 207].

The connection between force and life is also thematized by Petar II Petrović Njegoš, the Prince-Bishop of Montenegro. Poet and philosopher in addition to being a ruler, he attempted to essentially determine an Orthodox Christian understanding of force and violence. He only seldom used the word violence, yet even in his brief life (1813-1851), he managed to examine the meaning and importance of force and construct a fairly original justification and limit to justification of force. Why choose Njegoš here (aside from the partial biographical overlap with Tolstoy)? Because, essentially, he founded what corresponds to "Russian thought," which we could (today) call "Serbian thought." First, the historical moment when he lived opposing the Ottoman Empire (and Serbian traitors) - the various influences of the literature he reads, along with his informal education, the significance of Romanticism and the Romantic concept of force, to which we can add the Russian influence and his Orthodox Christian 'orientation' in war and in thinking about injustice - all of this together tells us that Njegoš is truly our contemporary. His letters and verses are brimming with discussions of righteousness of force and power, giving him a special place in the histories of justifying violence. It seems to be that Njegoš, including the way his life unfolded, can help us, above all, in a kind of preliminary differentiation of Orthodox Christian from a Romantic understanding of force and violence. In a letter to Jeremija M. Gagić, of 20 December 1830, seventeen-year-old Njegoš mentions the proverb that 'might makes right', he speaks of enduring suffering, but also, albeit very shyly, mentions defense and the need for us as a group to defend. This is a good example. I would 
like to insist that the Romantic understanding or justification of force always manipulates with various paradoxes through which force or violence "brings together unconnected entities" (law and force; violence and justice; "mace and law," which is Njegoš's favorite example). In all these examples, force and violence are placed with protocols that at first glance could never go with them. On the other hand, defense - more precisely, life as force and defense (the power to defend life) - could represent the basic form and introduction into the Orthodox Christian interpretation of violence and thus war. In his three main works, Luča mikrokozma [Ray of Microcosm] (1845), Gorski vijenac [Mountain Wreath] (1847), and Šćepan mali [Šćepan the Little] (1851), Njegoš constantly mixes these two registers, these two machines for justifying force. At the opening of Luča (Poem I), the poet imagines an "infinite force" (besputna sila) or "unholy force" (nečastiva sila) that can only be destroyed through the force of justice [5]. Justice, "blessed by the Creator's hand," has the capacity to protect from this exceptional force. Protection or the force of protection, the action that protects from violent force, is Njegoš's invention of the Orthodox Christian version of victorious force. Only protective force can defeat aggressive force or violence. Two years later, in "Mountain Wreath," he further develops this "protective or defensive action," spoken in several verses by the Abbot Stefan. Speaking of eternal war of everything against everything, and about the "infernal discord" in the world, Abbot Stefan explains the connection between force and (living) life:

The world demands some kind of firm action (dijejstvije),

duty gives birth to new obligations,

and defense is closely tied up with life!

Nature provides everything with weapons

against a force that is oft unbridled,

against trouble and dissatisfaction.

Sharp spikes are there to protect the corn stalks, and thorns defend a rose from being plucked.

Myriads of teeth has nature sharpened

and has pointed innumerable horns.

Various tree-barks, wings, and speed of feet,

and the array of seeming disorder,

always follow some definite order.

Over all this huge conglomeration

again a wise, mighty force reigns supreme.

It won't allow for evil to triumph.

It snuffs the spark, strikes the snake in the head. [5. P. 79].

"A wise force" is constituted as life, as that which lives defending itself immanently from that which endangers it. This is a novelty in constructing justifications of defensive forces. Njegoš sees the force of the Creator in giving life and then transferring that force onto all living things. Defense of life is the "action" of the Creator himself. A few years later, in Šcepan mali, a play, this becomes explicit in a dialogue on force between the Turkish master Beglerbeg and the 
Orthodox Christian Teodosije Mrkojević. The Turk insists on the "strength of force" as such:

Force, applied strong enough,

Makes even marrow weep [5. P. 206].

But although Beglerbeg equates the might of force with Sultan's, and then God's, will ("the Sultan wills what God wills), Teodosije Mrkojević decisively separates God's force from human (Sultan's) force [5. P. 207]. Divine force is stronger than any possible force, as it is at the heart of everything created, animate and inanimate, but exclusively as defensive force and force that resists external force (violence).

What, then, is this counter-violent force, force against violence? How shall we describe it? And how can we justify it? Must the one who makes use of it do so entirely correctly, unblemished (Ilyin speaks on occasion of a "sinless act of injustice")? Perhaps a more elaborate justification of use of force in response to violence, as well as the description of "the nature" of force (primarily its scope, not the technique of its conduct, although it is certainly not insignificant), would be made possible if we understood the particular situations of the actors in play: there is the violator, who is supposed to stop and abandon his action, the one who rejects the violence, who is also simultaneously supposed to hold themselves back before the aggressor.

Justification, if it is to be successful, converts force into counter-violent force. What is the connection between 'justification of force' (since only when justified does force not become violence) and counterposing or rejecting violence? Is the connection between the two always implicit?

Reason, justification, legitimacy of violence are not synonyms (that is, do not stand in synonymy: Hannah Arendt, for example, claims that violence [Gewalt] can be legitimate, but not justified; while Karsavin says that force can be necessary, but not justified). If we leave aside for a moment this difference between "justified force" and "justified" violence (by definition, violence is aggressive and attacking, so in the 'Russian' or 'Orthodox Christian' understanding cannot be either justified or necessary), proving that a force is counter-violent — which makes it unimportant whether justified or necessary - requires a protocol that should have universal validity, meaning be valid for all conflicting sides. In "Search for war's meaning" (1914), Semyon Frank has the "daunting task" (as he calls it) to produce a "conceptual justification of war, in an objective and moral way:

To justify war means showing that it is led for the right reason, that it is conditioned by the necessity of defense of human life or reaching objective principles of human virtue. Objective virtues imply that these are values held by all. In this way, justifying war means finding the foundation that would be binding for all. (...) Justifying war is possible only by citing those reasons with which the enemy has to agree [6. P. 408].

The protocol of counter-violence ("противонасилие"), as "justified force" necessarily possesses some immutable characteristics: first, violence is often if not 
always counter-violence, which is to say that violence is necessarily always already a response to violence. Anyone using force actually claims to be responding to violence that has already taken place, is taking place or is imminent. Second, the basic idea or characteristic of counter-violence is the force of interruption of all potential violence (making counter-violence the last violence) and achievement of something entirely new (in breaking with the old, the unjust, previous injustices, which allow and then often justify the use of the last injustice). Third, the protocol of justifying counter-violence necessarily contains a verification, debate, that is, an address to those who are a priori against (opposers to violence but also to counterviolent force), who stand against any response to violence (which usually refers to various forms of "Tolstoyism").

How then is war or violence interrupted? Is there something in violence (or counter-violence) that can really interrupt violence as such? Analogously, or better, as a counter-analogy, is there a violence we never oppose, that is, which does not imply counter-violence? Would this even be 'violence' or is 'violence' only the kind of violence and amount of force that necessarily implies a response to itself, that is counter-violence? There is, for example, violence we suffer without opposition, certain that otherwise we would be subject to still worse violence. Or violence transformed and institutionalized (so-called institutional violence, invisible symbolic violence), such that it has become invisible, to which we never respond. Further, we never respond to 'victorious' violence, that is, the institution of victory can 'erase' the violence that led up to it or from which it resulted. There would also be counter-violence as preventive violence against violence that has not yet taken place, or counter-violence that repairs injustice and returns to balance. What I am particularly interested in is the temporal and regulative dimension of counter-violence: as mentioned, by definition, a successful counter-violence is or ought to be momentary and "quick," as well as "contain its own opposite" (autoregulation), or a "capacity" to self-limit and stop. In a word - it needs to abolish itself.

Within any epistemological reconstruction of military theater (not just Russian or Orthodox Christian), if pacifism or a call to peace ("peace at any cost," as F. Rosenzweig says) appears among the enemy, the aggressor (and peace occurs when the attack ceases, when the violence stops), then this cessation of violence or call to peace can appear if and only if we are not inactive (Karsavin calls inaction a sin; inaction is a kind of negative social act). To better determine this kind of action or coercion, this minimal response to violence, as counter-violence, which comes from the Russian language and tradition of thinking about war, then it has to be urgent and swift. I or we ought to necessarily and immediately oppose the other or the others. This very position of "opposition" designates that it is necessary to accept and appease the violence of the other and urgently stop them (while preventive violence [preventive war, preventive counter-violence] is epistemologically incorrect since we do not know whether someone will actually attack [H. Putnam]). How can we suffer the violence of another? How can we stop the violence of another? What force can compel another to stop their violence? 
Ivan Ilyin uses several verbs, such as presechenie (stopping), zastavlenie (urging), ponuzhdenie (compelling), prinuzhdenie (enforcing), to define the forms of this "placement of (myself or us) across the way," "against" the other's attack. A minimal response to violence as counter-violence would include several protocols. The first would be the differentiation of force and violence. In The Essence of Legal Knowledge, speaking of axioms of state power (vlast), Ilyin writes about spiritual rectitude (duhovnaja pravota) as a mysterious force, since state power is a (military or legal) force.

Power (vlast) is above all force. (...) The essence of life consists in acting (dejstvii), and specifically in effective acting; the capacity for such acting is living force (zivaja sila). (...) Unlike any physical force, state power is intentional force. (...) "The sword" therefore does not express the essence of state power. (...) [7. P. 121] State power is the force of the will. [7. P. 122] (...) The first axiom of state power is that it cannot belong to anyone who does not possess legal authority (pravovogo polnomochiya) [7. P. 123].

This is followed by a very important passage for us:

\begin{abstract}
Moreover, legal consciousness demands that the power itself is perceived as having influence (force) inasmuch as it is authoritative and just rather than as the force instituting the law. The law is not born of force, but exclusively of the law and ultimately the natural law. This means that brute force that usurps power will institute positive law inasmuch as popular legal consciousness agrees (under whatever were its considerations) to recognize its authority [7. P. 123].
\end{abstract}

Yet, Ilyin still seems not to show clearly enough the 'asymmetric synonymy' of state power and force, which he wrote about in 1910 [8]. State power as force does not produce (give birth to) law, but only that state power which has a "living influence," which is force "in its correct measure." The one who stands in opposition actually represents this living influence, which, being right (as state power), makes law or gives order to social life. Further, neither violence nor "brute force" (a synonym for violence really) nor force create right. This is the innovation in the histories of justification of force or violence, absent in the West. Aggressive violence can necessarily be opposed only in a way that implies the possibility of constituting law and order. If we read Ilyin's 1924 "O soprotivlenii zlu siloyu" in concert with Ilyin's early and late texts on law, then it becomes clear that law is the basic regulative idea of the use of force. One opposes violence to the extent that the creation of right is thereby made possible. In that sense, force becomes but an "impulse of the development of law."

The third protocol that gives rise to law in force and continuously reiterates the limit of "counter-violence" refers to the work of metaphors and metonymies (which I still think cannot be subsumed under 'religious phraseology'). Sentences such as "his very sword will become a flaming prayer" or "may your sword be your prayer and your prayer be your sword" [9. P. 219], can certainly further impact the 
regulation of rejecting violence and a swift cessation of force. This protocol is certainly in harmony with Tolstoy's approach of ultimate abnegation of a response to violence.

\title{
References
}

[1] Laiou A, Morrisson C, Dorin R. (Eds.). Byzantium and the Other: Relations and Exchanges. London: Routledge; 2012. DOI:10.4324/9781351219747

[2] Tolstoy L. War and Peace. Transl. by L\&A. Maude. NY: Planet Book; 2011.

[3] Tolstoy LN. "The Kingdom of God Is Within You": Christianity Not As A Mystic Religion But As A New Theory of Life. Transl. by C. Garnet. NY: The Cassell Pub. Co; 1894.

[4] Tolstoy LN. The pathway of life. In: Complete works. Vol. 45. Moscow; 1956. Stable URL: http://tolstoy.ru/online/90/45/ [Accessed 30 June 2020]. (In Russian).

[5] Njegoš PP. Collected Works. Belgrade: Narodna kultura; 1936. (In Serbian).

[6] Frank SL. O poiskah smysla vojny. Russian philosophers about the war. Moscow: Kuchkovo pole; 2005. P. 402-412. (In Russian).

[7] Ilyin IA. Ch. 14. Axioms of power. In: Ilyin IA. On the Essence of Conscience of Law. Munich; 1956. P. 120-133. (In Russian).

[8] Ilyin IA. Concepts of law and force (1910). Collected Works. Vol. 4. Moscow: Russkaya kniga; 1994. P. 1-45. (In Russian).

[9] Ilyin IA. Resistance to Evil By Force. Berlin; 1924. (In Russian).

[10] Berdyaev N. Thoughts About The Nature Of War. Moscow: Russkaya ideya; 1997.

[11] Ivanov V. Legion and Sobornost'. In: Ivanov V. Collected Works. Bruxelles; 1979. Vol. 3. P. 253-261. Stable URL: http://www.v-ivanov.it/brussels/vol3/01text/ 02papers/3_140.htm [Accessed 30 June 2020]. (In Russian).

[12] Ilyin IA. Pro et Contra. St Petersburg; 2004. (In Russian).

[13] Bibikov PA. Phenomenology of war. Vremya. 1861;12:21-145. (In Russian).

[14] Kant I. Gesammelte Schriften. Bd. 27. Vol. 4. Berlin: De Gruyter; 1975. (In German).

[15] Kant I. AA XIX: Handschriftlicher Nachlaß. Moralphilosophie, Rechtsphilosophie und Religionsphilosophie. Stable URL: https://korpora.zim.uni-duisburg-essen.de/kant/ aa19/564.html [Accessed 30 June 2020] (In German).

[16] Gusejnov AA. Ponyatiya nasiliya i nenasiliya. Voprosy filosofii. 1994;4:35—41.

[17] Ballou A. Catéchisme Non-Résistant. 1844. Stable URL: https://fr.wikisource.org/ wiki/Catéchisme_non-résistant [Accessed 30 June 2020]

[18] Scheler M. Der Genius des Krieges und der Deutsche Krieg. Leipzig: Verlag der weissen Bücher; 1915. (In German).

[19] Kimelman R. Non-Violence in Talmud. Judaism. 1968;17(3):316-334.

[20] Štedimlija SM. Njegoševa formula sile. Nova Evropa. 1933;12:545—554. (In Serbian).

[21] Tolstoy LN. A Confession. What I Believe? Leningrad; 1991. (In Russian).

[22] Karsavin LP. Cerkov', lichnost' i gosudarstvo [Church, personality and state]. In: Karsavin LP. Works. Moscow: Raritet; 1993. P. 403-442. (In Russian).

[23] Lenin VI. Theory of violence (collection). Moscow: Algoritm; 2007. (In Russian).

\begin{abstract}
About the author:
Bojanic Petar - PhD, Full professor, Principal Research Fellow, Belgrade State University, Belgrade, Serbia; Ural Federal University, Ekaterinburg, Russia (e-mail: bojanic@instifdt.bg.ac.rs, bojanicp@gmail.com).
\end{abstract}




\title{
Насилие и противонасилие. О правильном отказе от насилия (Очерк возможной русской этики войны на основании понимания насилия Л. Толстым и Петаром Петровичем Ньегошем)
}

\author{
П. Боянич \\ ${ }^{1}$ Университет Белграда \\ Serbia, 11000, Belgrade, Studentski trg, 1 \\ ${ }^{2}$ Уральский федеральный университет \\ Российская Федерация, 620002, Екатеринбург, ул. Мира, 19
}

Цель статьи заключается в построении возможного минимального ответа на насилие, иными словами, в описании того, что было бы оправданным (необходимым или законным) «противонасилием». Этот аргумент основан на реконструкции нескольких важных философских текстов на русском языке первой половины XX века, а также на расширении анализа проблемы за пределы этого исторического момента. После реконструкции критики Л. Толстым любого применения насилия показывается, что, как это ни парадоксально, противники учения Толстого включили разработанную Толстым идею противонасилия в свои теории, в которых стремились легитимизировать применение силы. В частности, открытие Толстым силы, которая, с одной стороны, не основана на насилии, а, с другой стороны, способна противостоять насилию, становится основополагающим в рассуждениях о справедливом применении силы. Далее выстраивается связь между Л. Толстым и Петаром II Петровичем Ньегошем, который также тематизирует применение силы в христианской перспективе. По его мнению, справедливость, «благословенная рукой Творца», способна защитить от насильственной силы. Любое живое существо защищается от того, что ему угрожает теми средствами, которыми его одарил Творец. Живая сила и защитное применение силы концептуально связываются в рассуждениях Ньегоша. Таким образом, только защищающая сила может победить агрессивную силу. Это свидетельствует о вкладе Ньегоша в православный христианский дискурс о насилии. Если сила может быть противонасильственной, следующим шагом в нашем аргументе будет поиск протокола, который должен иметь универсальную силу, то есть он должен быть действительным для всех конфликтующих сторон. Протокол о борьбе с насилием требует, чтобы, во-первых, сила была ответом на насилие; во-вторых, прерывала насилие и предотвращала любое возможное насилие в будущем (это «последнее» насилие); в-третьих, применение силы подлежит проверке, обращено к тем, кто априори против любой ответ на насилие (что обычно относится к различным формам «толстовства»). Наконец, показано, что государственная власть не создает закон, а лишь правота создает закон, дает жизнь общественному порядку и тем самым может санкционировать применение силы. Это новшество в истории оправдания силы, отсутствующее на Западе. Агрессивному насилию может быть противопоставлена лишь та сила, которая предполагает возможность установления закона и порядка.

Ключевые слова: насилие, противонасилие, оправдание насилия, русская этика войны и насилия, православная этика войны и насилия, толстовство, этика Ильина

Информация о финансировании и благодарности. Исследование выполнено за счет гранта Российского научного фонда (проект №20-18-00240). 


\section{История статьи:}

Статья поступила 18.07.2020

Статья принята к публикации 24.08.2020

Для цитирования: Bojanić P. Violence and "Counter-Violence". On Correct Rejection. A Sketch of a Possible Russian Ethics of War Considered through the Understanding of Violence in Tolstoy and in Petar II Petrović Njegoš // Вестник Российского университета дружбы народов. Серия: Философия. 2020. T. 24. № 4. С. 657-668. DOI: 10.22363/23132302-2020-24-4-657-668

\section{Сведения об авторе:}

Боянич Петар - доктор философии, профессор, Университет Белграда, Белград, Сербия; Уральский федеральный университет, Екатеринбург, Россия (e-mail: bojanic@instifdt.bg.ac.rs, bojanicp@gmail.com). 